\title{
Burns in the Domestic Environment: Characteristics and Circumstances of Accidents ${ }^{1}$
}

\author{
Tatiane Meda Vendrusculo2 \\ Carmem Roberta Baldin Balieiro ${ }^{3}$ \\ Maria Elena Echevarría-Guanilo \\ Jayme Adriano Farina Junior ${ }^{5}$ \\ Lídia Aparecida Rossi ${ }^{6}$
}

This study characterizes burn accidents in the domestic environment and identifies the circumstances of accidents affecting children, adults or elderly people who need supervision or care. Demographic data and burn characteristics of 61 domestic environment burn victims were collected. The family members of 13 children and one aged adult, who needed supervision or special care, were selected to answer a semi-structured interview. Two thematic groups were identified: social and environmental factors that might have contributed to the burn accidents and circumstances involving the accidents. Risk factors were: low socioeconomic and educational levels of mothers and those responsible for the children at the moment of the accident, small houses considering the number of occupants and unsafe kitchen equipment. Although cases of domestic violence were not identified there was neglect from caregivers. Health professionals should be attentive and investigate the circumstances of accidents involving vulnerable individuals.

Descriptors: Burns; Accidents, Home; Child Abuse.

\footnotetext{
${ }^{1}$ Article extracted from course conclusion monograph "Queimaduras em ambiente doméstico: características e perspectivas de familiares sobre as circunstâncias do acidente" presented to Escola de Enfermagem de Ribeirão Preto, Universidade de São Paulo, WHO Collaborating Centre for Nursing Research Development, SP, Brazil.

2 Nursing Undergraduate Student, Escola de Enfermagem de Ribeirão Preto, Universidade de São Paulo. Scholarship holder, Basic Scientific Program CNPq. E-mail: tatiane_mv@hotmail.com.

3 Psychologist, M.Sc. in Nursing. E-mail: crbalieiro@uol.com.br.

${ }^{4} \mathrm{RN}$, Doctoral Student, Programa Interunidades de Doutoramento em Enfermagem, Escola de Enfermagem e Escola de Enfermagem de Ribeirão Preto, Universidade de São Paulo, Brazil. E-mail: bbpino@hotmail.com.

${ }^{5}$ Physician, Ph.D. Surgery, Faculty, Faculdade de Medicina de Ribeirão Preto, Universidade de São Paulo, Brazil. Director, Divisão de Cirurgia Plástica, Unidade de Queimados, Hospital das Clínicas, Faculdade de Medicina de Ribeirão Preto, Universidade de São Paulo, Brazil. E-mail: farinajunior@directnet.com.br.

${ }^{6}$ RN, Ph.D. in Nursing, Associate Professor, Escola de Enfermagem de Ribeirão Preto, Universidade de São Paulo, Brazil. E-mail: rizzardo@eerp.usp.br.
} 


\title{
Queimaduras em ambiente doméstico: características e circunstâncias do acidente
}

Este estudo teve como objetivos caracterizar os acidentes por queimaduras, ocorridos em ambiente doméstico e identificar as circunstâncias desses acidentes quando atingiram crianças, adultos ou idosos que necessitavam de supervisão. Foram coletados dados demográficos e sobre o trauma de 61 vítimas de queimaduras em ambiente doméstico. Dessas, 13 crianças e um idoso, com necessidade de supervisão ou cuidado especial, tiveram os familiares selecionados para entrevista semiestruturada. Foram identificados dois núcleos temáticos: fatores que podem ter contribuído para a ocorrência de acidentes por queimaduras: sociais e ambientais e circunstâncias que envolveram o acidente. Os fatores de risco foram: baixo nível socioeconômico e de instrução das mães e responsáveis pela criança, no momento do acidente, moradias pequenas para o número de residentes e equipamentos de cozinha precários. Não foram identificados casos de violência doméstica, mas de desatenção dos responsáveis. Os profissionais da saúde devem estar atentos para investigar as circunstâncias dos acidentes em indivíduos vulneráveis.

Descritores: Queimaduras; Acidentes Domésticos; Maus-Tratos Infantis.

\section{Quemaduras en ambiente doméstico: características y circunstancias del accidente}

\begin{abstract}
Este estudio tuvo como objetivos caracterizar los accidentes por quemaduras, ocurridos en ambiente doméstico, e identificar las circunstancias de esos accidentes cuando afectaron niños, adultos o ancianos que necesitaban de supervisión. Fueron recolectados datos demográficos y sobre el trauma de 61 víctimas de quemaduras en ambiente doméstico. De esas, 13 niños y un anciano, con necesidad de supervisión o cuidado especial, tuvieron los familiares seleccionados para entrevista semiestructurada. Fueron identificados dos núcleos temáticos: factores que pueden haber contribuido para la ocurrencia de accidentes por quemaduras: sociales y ambientales $y$, circunstancias que envolvieron el accidente. Los factores de riesgo fueron: bajo nivel socioeconómico y de instrucción de las madres responsables por el niño en el momento del accidente, habitaciones pequeñas para el número de residentes, $y$, equipamientos de cocina precarios. No fueron identificados casos de violencia doméstica, pero de si de falta de atención de los responsables. Los profesionales de la salud deben estar atentos para investigar las circunstancias de los accidentes en individuos vulnerables.
\end{abstract}

Descriptores: Quemaduras; Accidentes Domésticos; Maltrato a los Niños.

\section{Introduction}

Burn is always an overwhelming trauma since it leaves one dependent to others for even the minimum requirements of survival. In a few seconds, a trauma like this makes a person experience terrible pain and become completely dependent. Burns are often associated with domestic violence when it affects children, elderly and people with little or no ability to defend themselves, which is an aspect fairly uninvestigated in Brazil.
There is, in research addressing the epidemiology of burns, a greater focus on the types, depth and extension of burns, affected areas ${ }^{(1-2)}$, sequela(3-4), the accidents' circumstances and sites, and the presence or absence of a caregiver at the moment of the accident(5). Few studies focus on the perspective of the victims' parents or caregivers concerning the accident's possible causes $^{(6)}$. 
Studies carried out in various countries such as France $^{(4)}$, Brazil(5-6) $^{\left(5 e r u^{(7)}\right.}$ and Switzerland( ${ }^{(8)}$ have shown that the majority of burn accidents occur in a domestic environment and affect children and that scalding is the main causal agent. A high prevalence of burns in elderly people with neurological impairment was observed in Canada and hot water in the bathtub was the main agent ${ }^{(9)}$. Patients with epilepsy are at a higher risk of deep burns, especially when they experience a seizure while performing daily activities at home ${ }^{(10)}$. The characteristics of burn accidents with neuropsychiatric patients in a study carried out in Japan were analyzed and these patients presented larger total body surface area burn (TBSA) and higher mortality when compared with the control group composed of healthy people suffering burn accidents ${ }^{(11)}$.

Other authors studied the risk factors for burns in children and concluded that the factors increasing the risk of these accidents are: absence of tap water, overcrowding of people in the same family environment and low income. Low risk factors are: houses with a larger number of rooms, parents' higher educational level, homeownership and other factors that indicate higher socioeconomic status( ${ }^{(7)}$. One study carried out with children in England presented the characteristics of burn traumas and the assumption that burns can be considered due to the negligence of the caregiver at the moment of the accident ${ }^{(12)}$.

One study carried out in Brazil stresses the importance of collecting data from the victim's history along with a physical assessment and, in case inconsistencies are found, that a deeper investigation is warranted. This study reports the severity of the problem in Brazil(13). According to data from a systematic literature review, the following factors might lead to the suspicion of mistreatment in burn accidents: scalding with a symmetric distribution pattern (extremities with sock-like or glove-like lesions), younger than six years old, incompatibility of the accident with the child's age, inconsistent reports, people with cognitive problems, associated lesions, previous traumas and sociodemographic and socioeconomic factors (unemployment and low family income and families headed by women) $)^{(14)}$.

Intra-family (or domestic) violence in Brazil is not a new problem for health professionals. Professionals are in daily contact with this in outpatient clinics and emergency rooms ${ }^{(15)}$. Domestic violence can be experienced in all cultures and social classes, though, specific characteristics can be identified in families that practice mistreatment such as the absence of the father, families headed by women and low income(15). Children who arrive at the hospital with severe injuries such as burns, fractures, traumas or poisoning probably suffered previous, less severe, mistreatment that were unidentified or unreported ${ }^{(15)}$.

Negligence is characterized by privation of something one needs, that is, it might mean the omission of basic care such as medication and food and absence of protection against the elements (cold, heat) (15). Abandonment is a type of abuse characterized by the absence of a caregiver, and is classified as partial, when the absence of the caregiver is temporary and exposes the victim to risk situations, and as total abandonment when the child is removed from the family and is left homeless, helpless and exposed to numerous risk situations ${ }^{(15)}$.

Despite agreement in the literature about the characteristics of burns involving abuse and studies indicating the circumstances of burns and the presence or absence of a caregiver at the moment of the accident as risk factors to be considered in this kind of accident, the studies published so far have not sufficiently explored these aspects. Hence, an important question to be investigated is the perspective of family members or caregivers of burn victims concerning the factors that contributed to the event, especially in the case of domestic accidents and when victims are dependent on someone else. Thus, this study characterizes burn accidents that occurred in the domestic environment and identified the circumstances involving these accidents when children, adults or elderly, who needed special care or supervision, were affected.

\section{Material and Method}

The concepts related to domestic abuse and the characteristics that identify mistreatment in the form of burns found in systematic literature reviews were used as the theoretical framework in this study ${ }^{(14)}$.

A case-series observational and descriptive study with quantitative and qualitative approaches was carried out in the Burn Unit at the Hospital das Clinicas at the University of São Paulo at Ribeirão Preto, Medical School (BU-HCFMRP) after approval was obtained from the institution's Research Ethics Committee. There are ten beds for adult and pediatric inpatients and two rooms to care for outpatients in this unit.

Data from all patients admitted into the BU-HCFMRP in the acute phase of a burn experienced in a domestic 
environment were collected from July 2007 to July 2008 in the study's first phase. Convenience sampling was used in this phase ${ }^{(16)}$.

This study was developed in two stages with distinct methodological designs. The patients who suffered domestic accidents and were admitted during the studied period were characterized in the study's first stage. In the second stage, case studies, interviews and direct observation were used to investigate each family and identify the circumstances of the accidents involving children, adults or elderly people who required some special care or supervision.

The participants of the first stage were all admitted into the unit during the studied period in the acute phase of a burn suffered in a domestic environment. The participants of the second phase were children, adult and elderly people who needed supervision or care before the accident (for example, those who could not perform routine tasks), children younger than 12 years old and people with a diagnosis of epilepsy or other disease that could have triggered the accident during a seizure, the caregivers of the victim at the moment of the accident in the case of those older than 12 years of age and the victims' parents or legal guardians. Family members, legal guardians or caregivers present at the moment of the accident were excluded when, even after being invited three times, they did not come to the unit.

A total of 195 patients were admitted in the studied period and 77 of these were hospitalized to undergo reconstructive surgery to correct previous burns and 118 to treat acute phase burns. Sixty-one out of 118 patients suffered domestic accidents and participated in the study's first stage, 22 met the inclusion criteria to participate in the study's second stage. Of these, 14 patients participated in the second stage since eight family members or legal guardians could not be contacted. They did not regularly visit the unit during the study period and did not answer the invitation to participate in the study.

Among those patients admitted during the study's timeframe, 13 children and one elderly patient participated in the second phase, whose family members or legal guardians were directly observed and answered a semi-structured interview.

One instrument was used to collect the following data: patient's identification, burn causing agent, TBSA, depth, site where the accident occurred and a brief report of the event. This instrument included questions about the victim's family composition, socioeconomic status and viewpoints of family members and legal guardians about the circumstances of the accident. The data collection instrument was submitted to the evaluation of four professionals who work in care delivery for burn patients so that they could evaluate the instrument's face validity and content with a view to refine it. After this stage, a pretest was carried out ${ }^{(16)}$.

Data from all participants concerning the characterization of the accident and sociodemographic information were collected from the patients' medical files at the BU-HCFMRP. The 14 family members and legal guardians who participated in the second phase took part in semi-structured interviews and were directly observed. Participants were asked to describe how the accident happened, where it happened, the people involved, the people present at the moment of the accident and what the caregiver was doing at the time. They were also asked to describe the houses involved, the number of people living in the houses, level of education, profession and family income. Interviews were recorded and individually applied. The relationship between parents and legal guardians was observed during their stay in the Burn Unit (as companions or visitors).

Qualitative data were analyzed considering the following stages: reduction, data presentation and verification, and conclusion(17). Units of meanings, groups of meanings and thematic groups emerged from this process. After the transcription of interviews, we proceeded to the identification of codes, grouping of similar codes and construction of categories. These categories portray the circumstances involving the accident; aspects reported by the participants who try to explain how and why the accident happened according to their perspectives. This analysis also aimed to identify the accident circumstances and, according to its characteristics, whether there was evidence or suspicion of abuse or negligence ${ }^{(15)}$. Demographic data and those related to the accident were analyzed using the SPSS 15.0 program.

\section{Results}

In relation to the first stage, of the 61 patients who were burned in a domestic environment, 20 were less than 12 years old, 34 were between 12 and 59 years old and seven were older than 60 years old. Thirty-six patients were male. Direct flame in which alcohol was the main agent was the most frequent cause of accidents among adult and elderly patients (16) and scalding among children (11). Most of the accidents occurred in the house's external area followed by the kitchen. 
The average of TBSA of 61 patients was $14.6 \%$, while the average of TBSA among adult and elderly patients were $16.6 \%$ and among children was $10.9 \%$. The depth of burns was, in most of the cases, second or third degree.

In relation to the second stage, the majority of the 14 victims were female (10 patients); average age was nine years and three months (from $<1$ to 80 years of age), 11 patients were younger than six years of age, two were between 7 and 12 years old and only one patient was 80 years old. In relation to the TBSA, the average was $13.8 \%(0.5 \%$ to $34.5 \%)$. Scalding was the etiologic agent found in the majority of cases (six), followed by direct flame (five) and alcohol (three).

In this group, the kitchen was the place where most of the accidents occurred and all accidents by scalding happened in this room and did not present characteristics of an intentional event. However, family members reported they were absent at the moment of the accident or were not attentive to the child's protection in face of risk situations.

Table 1 presents the general characteristics of burn patients' family members, formally interviewed in this study: gender, age, educational level, marital status and kinship.

Table 1 - Characterization of burn patients' family members according to gender, age, educational level, marital status and kinship

\begin{tabular}{|c|c|c|c|c|c|c|c|}
\hline Identification & Gender & $\begin{array}{c}\text { Age } \\
\text { (years) }\end{array}$ & Occupation & Family income & Educational level & $\begin{array}{l}\text { Marital } \\
\text { status }\end{array}$ & Kinship \\
\hline 1 & $\mathrm{~F}$ & 20 & Housewife & $<2 x$ minimum wage & Completed primary school & Married & Mother \\
\hline 2 & $\mathrm{~F}$ & 22 & Housewife & $<2 x$ minimum wage & Completed primary school & Married & Mother \\
\hline 3 & $\mathrm{~F}$ & 40 & Agricultural worker & $<3 x$ minimum wage & Completed primary school & Married & Mother \\
\hline 4 & $\mathrm{~F}$ & 19 & Maid & $\mathrm{NI}$ & Completed primary school & Cohabitates & Mother \\
\hline 5 & $\mathrm{~F}$ & 34 & Maid & $<2 x$ minimum wage & Completed primary school & Married & Mother \\
\hline 6 & $\mathrm{~F}$ & 41 & Agricultural worker & $<1 \mathrm{x}$ minimum wage & Completed primary school & Divorced & Daughter \\
\hline 7 & $\mathrm{~F}$ & 42 & Maid & $<4 \mathrm{x}$ minimum wage & Completed primary school & Cohabitates & Mother \\
\hline 8 & $\mathrm{~F}$ & 31 & Hair stylist & $<13 x$ minimum wage & Completed secondary school & Married & Aunt \\
\hline 9 & $\mathrm{~F}$ & 20 & Housewife & $<2 x$ minimum wage & Completed primary school & Cohabitates & Mother \\
\hline 10 & $\mathrm{~F}$ & 26 & Housewife & $<2 x$ minimum wage & Completed primary school & Cohabitates & Mother \\
\hline 11 & $\mathrm{~F}$ & 21 & Housewife & $\mathrm{NI}$ & Completed primary school & Single & Mother \\
\hline 12 & $\mathrm{~F}$ & 22 & Housewife & $<1 \mathrm{x}$ minimum wage & Completed secondary school & Married & Mother \\
\hline 13 & $\mathrm{~F}$ & 31 & Housewife & $<2 x$ minimum wage & Completed primary school & Married & Mother \\
\hline 14 & $\mathrm{~F}$ & 36 & Housewife & $<1 \mathrm{x}$ minimum wage & Illiterate & Cohabitates & Mother \\
\hline
\end{tabular}

NI: Not informed

${ }^{* *}$ Minimum wage $\simeq$ USD 230.00

All interviewed family members were women and the majority were the burn patient's mother (12). The average age of these individuals were 28.9 years old (Table 1). Eight out of the 14 interviewed women did not have a paid job.

According to Table 1,11 of the 14 interviewed family members had not completed primary school and one had never attended school. The majority (11) had family income lower than two times the minimum wage, including three families who had income lower than the minimum wage.

The 14 participants lived in houses with few rooms, considered small for the number of residents. Relationship problems were not observed between family members and patients during the observations and interviews. Although informed of the study objectives, the participants were uneasy and showed distrust during interviews.

Based on analysis of data obtained from the interviews and which characterized the nuclear family in which the burned victim was included, two thematic groups were identified: social and environmental factors that might have contributed to the accidents and circumstances involved in the accident.

\section{Social and environmental factors that might have contributed to the burn accidents}

The reports of participants revealed that the mother or caregiver performs activities that involve risks of burn accidents in the presence of children or permit them to perform risky activities themselves, such as playing with alcohol or cooking, boiling water and other liquids in the presence of children playing around (...) I went to fetch water from the tank (...) I had already put some water in the pot to cook (...) on the stove and she was behind me playing, so she screamed and when I got there, she had climbed onto the stove (...) and pulled the back pot (Family member 7). I was in the kitchen and I put grease on to warm up, so I turned to the sink to do the dishes and she was playing with a little squeegee, so she hit the squeegee and the pot turned over on her (Family member 9). 
Participants reported the use of old stoves with gas leakage and pots with broken handles. Some reported they did not worry about the organization of pots on the stove while they were cooking and kept handles facing out where children could reach them, as exemplified in the following reports: (...) I didn't care the way I organized (pots on the stove) on the stove, as I was used to do. You know, she always played in the kitchen but never did that (pull the pot) (Family member 11). It wasn't a habit, I never got concerned with the handle facing out, but now I'll always put it facing in (Family member 12).

\section{Circumstances involving the accident}

In the category 'circumstances involving the accident', aspects related to the history of the burn accident that reveal how the accident happened and whether there were adults or caregivers around and what these people did and how they acted after the accident are presented.

The reports revealed that the family member is away for a few minutes, leaving the child in a situation of risk as shown in the following examples: The candle was near the baby stroller, on the top of a table. It must have been blown (...) and it must have fallen into the baby stroller(...). I was laid down and fell asleep. So that's how the accident happened (Family member 1 ). I went to prepare her breakfast (...)I turned my back for about five minutes, she stirred up the teapot, jumped on a chair and moved it (Family member 4).

All accidents occurred in the presence of a person older than the victims and in five cases we can state that somehow those people present at the moment of the accident contributed to the accident to happen: (...) $\mathrm{He}$ (the older neighbor) poured the rest of the liter of alcohol (in the cart of cans) he threw the match and the fire together and she was in the front, it sprayed on her and caught her on fire (Family member 3). (...) They (burn victim and an older cousin) were taking a tick off the dog and putting everything into a container with alcohol...At the end they set fire on the alcohol in the container (...) She (older cousin) got the closed container of alcohol and gave it her (...). Then she got it and when she turned it, it exploded (Family member 8). My husband went to burn the trash in front of our house, so we went inside (...), then he (burn victim) went running and tripped over a broom he (husband) had and fell with his hand over the fire (Family member 10). (...) While I went to answer the cell phone in the bedroom (...), very fast, his 11-year old sister climbed the chair and got the alcohol up there in the cupboard (...) she got alcohol and a lighter, which was up there also, gave him alcohol, ran to the backyard and told him to pour it fast. So when she light up the fire, it went onto him, he had the alcohol in his hands (...) (Family member 13).

The only elderly participating in this study was completely dependent on a caregiver, and since round the clock care was not provided for him, he died due to the burns. This dependency, acknowledged by the family member, can be observed in the following excerpt: most of the day he'd stay alone. I'd get at home at 5:00, 5:30 pm and would bath him, I'd first take care of him, sometimes, dinner was ready and I'd warm it up and give it to him. I was the one who shaved him, cut his nails, because my dad had a stroke, so he lost the fingers movement, he didn't move his hands anymore, about nine years ago he had the beginning of a stroke (...). He had a problem in his foot and his foot was crooked. He couldn't walk either because he also had a back problem, took medication for his back, but the medication would finish and nothing would change (...). We lived next door, because he'd stayed more by himself and I live next door and the window of my bedroom was in front of his window (...). I was sleeping (...) it was 7o'clock; I woke up and saw the smoke (Family member 6).

\section{Discussion}

We observed that data of this study concerning the characteristics of the accidents that happened in domestic environments do not differ from other studies carried out in Brazil(5-6). The majority of accidents occur in a domestic environment and mainly affect children ${ }^{(4-5,7-8)}$.

Direct flame combined with alcohol is the main cause of accidents in Brazil; it occurs in the external areas of the house and affects school-aged children and adults. This kind of accident for adults is mainly related to the common practice of lighting up charcoal barbecues with alcohol, and in children, these accidents are related to playing in the backyard and mainly affect male individuals(5).

In relation to the participants who required special care or supervision, burns did not present characteristics of an intentional event and, even though mothers showed distrust during the reports while providing information, situations that characterized abuse such as previous history of burns, reports inconsistent with the trauma characteristics, uniformity of burn depth such as sock-like or glove-like burns on the extremities were not found in this study ${ }^{(14,18)}$. The characteristics of the observed accidents in general where those that affect children in domestic environments and are associated with low income populations with low levels of education, especially mothers ${ }^{(3,7)}$. The low level of education partially 
explains the fact that mothers permitted, or carried out themselves, certain practices that involve risk situations such as allowing children to stay or play near the stove while they cook, pour hot oil in front of the kitchen, get rid of ticks with alcohol, light up barbecues with alcohol (activities performed with children or in their presence). Considering the 14 studied cases, scalding was the most frequent etiological agent and the kitchen was the site where most of the accidents happened, as observed by studies carried out in different countries ${ }^{(4,7-8)}$.

The poor condition of appliances and utensils used in the kitchen such as stoves and pots was also identified as a risk factor for domestic accidents in this study. The authors of this study found in a previous study that family members of burned people and the patients themselves rarely identify risk situations for burns in their homes(6).

Additionally, living conditions might have facilitated the occurrence of these accidents since, as reported by the participants, the majority of the houses were small considering the number of residents, with few rooms, which approximates bedrooms, living room, kitchen and backyard. This fact was also reported in another study that identified that the overcrowding of people in the same house is a risk factor for the occurrence of domestic accidents( ${ }^{(7)}$.

Although situations that could raise suspicions that burns were not accidental were not identified, there were cases that can be characterized as negligence ${ }^{(15)}$ such as privation of basic care and absence of protection in a situation of risk for burns and in some cases, increased exposure to risk, as it occurred with the elderly patient who lived by himself, though he was totally dependent on people to perform basic activities.

We observed in all the reports that these accidents could have been avoided if adults were more attentive to the people who need care, protecting them in various situations that represent risk factors for accidents. These families have some characteristics that have been reported in the literature and are related to domestic abuse, for example, the victims' age is lower than six years of age, low level of education and low family income ${ }^{(14-15)}$.

Concerning a previous study published in this same periodical(6), this study contributes to show that even when people need special supervision and care, caregivers are not concerned to protect them from burn risks.

\section{Final Considerations}

This study addressed burns in people who need special care and supervision, especially elderly and children, who represent vulnerable groups in society. Although no domestic violence were identified among the studied cases, we consider important to signalize to health professionals caring for these groups the need to pay attention and investigate circumstances involving burn accidents.

In the studied group burns affected mainly children and adults in productive age. Burns affecting school age children and adults were caused by direct flame in which alcohol was the main agent and burns affecting children younger than three years of age were caused by superheated liquids.

Non-accidental burns were not found in this study but the results show that mothers with low level of schooling were more frequently responsible for children at the moment of the accident. Additionally, even though they do not recognize the risks, these individuals live in environments conducive to this type of injury and it is possible they did not heed the need to provide protection required by vulnerable individuals.

This study's results reinforce the need to implement programs to prevent burns directed to people with low level of education, mainly addressing the domestic environment. Teaching children in schools can also contribute to prevent accidents, since children are very sensitive and open to new information.

\section{References}

1. Duggan D, Quine S. Burn injuries and characteristics of burn patients in New South Wales, Australia. Burns. 1995 Mar; 21(2):83-9.

2. Rawlins JM, Khan AA, Shenton AF, Sharpe DT. Epidemiology and outcome analysis of 208 children with burns attending anemergency department. Pediatr Emerg Care. 2007 May;23(5):289-93.

3. Cronin KJ, Butler PE, McHugh M, Edwards G. A 1-year prospective study of burns in an Irish paediatric burns unit. Burns. 1996 May; 22(3):221-4.

4. Mercier C, Blond MH. Epidemiological survey of childhood burn injuries in France. Burns. 1996 February; 22(1):29-34.
5. Rossi LA, Braga EC, Barruffini RC, Carvalho EC. Childhood burn injuries: circumstances of occurrences and their prevention in Ribeirao Preto, Brazil. Burns. 1998 August; 24(5):416-9.

6. Rossi LA, Ferreira E, Costa EC, Bergamasco EC, Camargo C. Burn prevention: perception of the patients and their relative. Rev Latinoam Enfermagem. 2003 Jan-Feb; 11(1):36-42.

7. Delgado J, Ramirez-Cardich ME, Gilman RH, Lavarello $R$, Dahodwala N, Bazan A, et al. Risk factors for burns in children: crowding, poverty, and poor maternal education. Inj Prev. 2002 Mar; $8(1): 38-41$. 
8. Carlsson A, Uden G, Hakansson A, Karlsson ED. Burn injuries in small children, a population-based study in Sweden. J Clin Nurs. 2006 Feb; 15(2):129-34.

9. Hill AJ, Germa F, Boyle JC. Burns in older people--outcomes and risk factors. J Am Geriatr Soc. 2002 Nov; 50(11):1912-3.

10. Karacaoglan N, Uysal A. Deep burns following epileptic seizures. Burns. 1995 Nov; 21(7):546-9.

11. Yanagawa $Y$, Saitoh D, Sakamoto T, Okada Y. Unfavorable outcome of burn patients with neuropsychiatric disorders. Tohoku J Exp Med. 2005 Mar; 205(3):241-5.

12. Chester DL, Jose RM, Aldlyami E, King H, Moiemen NS. Nonaccidental burns in children--are we neglecting neglect? Burns. 2006 Mar; 32(2):222-8.

13. Leonardi DF, Vedovato JW, Werlang PM, Torres OM. Child burn: accident, neglect or abuse. A case report. Burns. 1999 Feb; 25(1):69-71.
14. Greenbaum AR, Horton JB, Williams CJ, Shah M, Dunn KW. Burn injuries inflicted on children or the elderly: a framework for clinical and forensic assessment. Plast Reconstr Surg. 2006 Aug; $118(2): 46 \mathrm{e}-58 \mathrm{e}$

15. Deslandes SF. Prevenir a violência: um desafio para profissionais de saúde. Rio de Janeiro: FIOCRUZ/ENSP/CLAVES; 1994.

16. Polit DF, Beck CT, Hungler BP. Fundamentos de Pesquisa em enfermagem: Métodos, avaliação e utilização. Porto Alegre: Artmed; 2004.

17. Miles MB, Huberman AM. Qualitative data analysis: an expanded sourcebook. London: Sage Publications; 1994.

18. Maguire S, Moynihan S, Mann M, Potokar T, Kemp AM. A systematic review of the features that indicate intentional scalds in children. Burns. 2008 December; 34(8):1072-81. 